\title{
Lighting Improvement in Building Renovation
}

\author{
Dina Maizana ${ }^{1}$ Syarifah Muthia Putri ${ }^{\varpi_{2}}$, Muhammad Rizal Irhami ${ }^{3}$ \\ 1Electrical Engineering, Universitas Medan Area, Jl. Kolam No. 1, Medan, 20223, \\ Indonesia,maizanadina@gmail.com \\ 2Electrical Engineering, Universitas Medan Area, Jl. Kolam No. 1, Medan, 20223, Indonesia, \\ syarifahmuthiaputri@gmail.com \\ ${ }^{3}$ Electrical Engineering, Universitas Medan Area, Jl. Kolam No. 1, Medan, 20223, Indonesia, \\ rizal.irhami12@gmail.com
}

${ }^{\circledR}$ Corresponding Author: syarifahmuthiaputri@gmail.com | Phone: +6285262058398

Received : February 4, 2021

Revision : February 17, 2021

Accepted : March 5, 2021

\begin{abstract}
Lighting systems that are not up to standard will have an impact on eye fatigue so that the work results of the staff are not optimal. This problem can be solved by designing a lighting system according to the standards that have been determined through the results of previous studies. The 1st floor of the Faculty Engineering, Universitas Medan Area building requires lighting improvements to provide comfort to all staff and lecturers. This research was conducted by measuring the value of light intensity in each room and improving the lighting system which was analyzed through the shape of the room, the color of the walls, and the position of the lights. The results of the research provide additional light points and lamp positions so that they are in accordance with the standard of utilization. Lighting according to the standard in the building of the Faculty of Engineering, Universitas Medan Area has been suitable to improve staff performance.
\end{abstract}

Keywords : eye fatigue, illumination, lighting standard

\section{Introduction}

Electrical installation is an important component of a building. Electrical installation in a building must be planned and implemented in accordance with applicable standards and regulations in order to obtain an efficient and safe electrical system. General Electrical Installation Requirements/Persyaratan Umum Instalasi Listrik (PUIL) are rules related to electrical installations. PUIL provides requirements for the design, installation and verification of electrical installations. So that it can provide safety to humans, livestock, and property that might arise in the use of electrical installations. Improved performance through standardized electrical installations can provide benefits in the form of electrical short circuit safety, simplifying maintenance or checking, simplifying interior design arrangements, and making comfort.

Lights as the main device used in a building have a big effect. Lighting that fits the standard will provide viewing comfort for the occupants. This comfort can allow residents to do their activities optimally. Planning for room lighting with lamps is carried out by considering the dimensions of the room, the color of the walls, and the position of the lamp.

The renovated $1^{\text {st }}$ floor the Faculty of Engineering, Universitas Medan Area, has a bad lighting system that requires improvement in term of lighting. The carried out of this paper is tocomply the lighting with lighting standard. When the lighting standard is achieved, the staff can work comfortably and optimally.

\section{Literature Review}

\section{- Room lighting system}

The lighting system or lighting in the room must pay attention to the supporting factors in order to produce a good lighting system (Wagiman, K.R \& Abdullah, M. N, 2017). The factors that affect lighting, namely:

1. Light flux

Light flux is a light source in the form of light streaks and emits light in all directions. The unit of light flux is the lumen.

2. Light intensity 
Light intensity is the light flux emitted in a certain direction per unit corner of a certain room. The unit of light intensity is candela.

3. Illumination

Illumination is the intensity of light on a plane. The unit of illumination is lux.

The Faculty of Engineering, University of Medan Area is a building in an educational institution that requires lighting according to standards and can be seen in the following table 1:

Table 1. Illumination Standard (Phillips Lighting Manual, 2015)

\begin{tabular}{cc}
\hline Room Function & Illumination (lux) \\
\hline Classroom & 250 \\
\hline Library & 300 \\
\hline Laboratory & 500 \\
\hline Kitchen & 250 \\
\hline Toilet & 250 \\
\hline Dean's Room & 350 \\
\hline Staff Room & 350 \\
\hline Meeting Room & 300 \\
\hline Archive Warehouse & 150
\end{tabular}

\section{- The Shape of a Room}

The shape of a room affects the quality of the lighting because it relates to the large in that shape (Feri, D, Anita, H, 2014). The figure 1 shows that squares will create a larger area than circles and triangles.
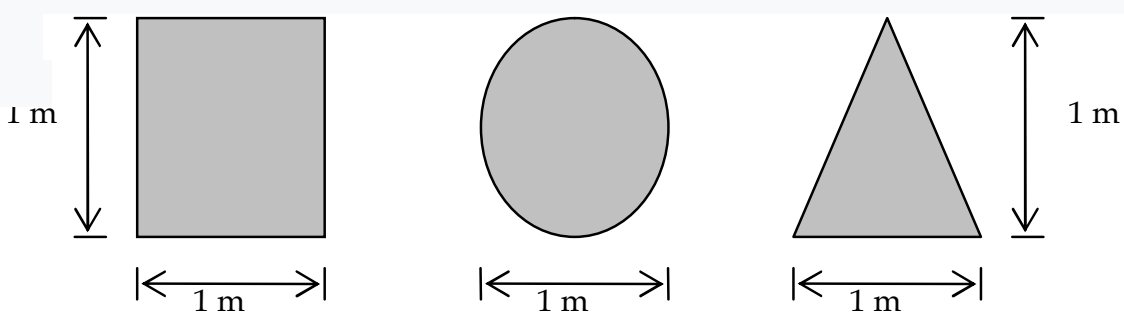

Figure 1. The Forms of Room

Table 2. Large of Area

\begin{tabular}{cc}
\hline Room form & Area $\left[\mathrm{m}^{2}\right]$ \\
\hline Foursquare & 1 \\
\hline Cycle & 0.785 \\
\hline Triangle & 0.5 \\
\hline
\end{tabular}

Table 3. Lumen Size Measure for Different Lamp with is same Watt.

\begin{tabular}{cc}
\hline The type of lamp & Luminous flux [lm] \\
\hline Bulb & $1500-2200$ \\
\hline Fluorescent lamp & $4500-7000$ \\
\hline Mercury lamp & $3500-6000$ \\
\hline
\end{tabular}

Illuminance or strength of lighting at one point on the area which the light is falling can be calculated by using the formula below. 


$$
\mathrm{E}=\frac{\phi}{F}[1 \mathrm{x}]
$$

where $\phi$ is luminous flux $[\mathrm{lm}]$

$\mathrm{F}$ is area which the light is fall $\left[\mathrm{m}^{2}\right]$

By using the data table 2 and 3 and substitute into equation (1) will be obtained illuminance that produced at the room with different room form is shown in table 4 :

Table 4. Influence Room Form to Illuminance

\begin{tabular}{cccc}
\hline \multirow{2}{*}{ The Form of Room } & \multicolumn{3}{c}{ Illumination [lx] } \\
\cline { 2 - 4 } & Bulb & Fluorescent lamp & Mercury lamp \\
\hline Foursquare & $1500-2200$ & $4500-7000$ & $3500-6000$ \\
\hline Cycle & $1900-2800$ & $5730-8917$ & $4460-7640$ \\
\hline Triangle & $3000-4400$ & $9000-14000$ & $7000-12000$ \\
\hline
\end{tabular}

- The quality of the lighting at the lamp position

The position of the lights in a room is usually placed at the top and in the middle of the room. Adjustment of lamp position is carried out to obtain lighting power according to the purpose by the room user (Dila, H, 2014). Some examples of lamp positions can be seen in the picture

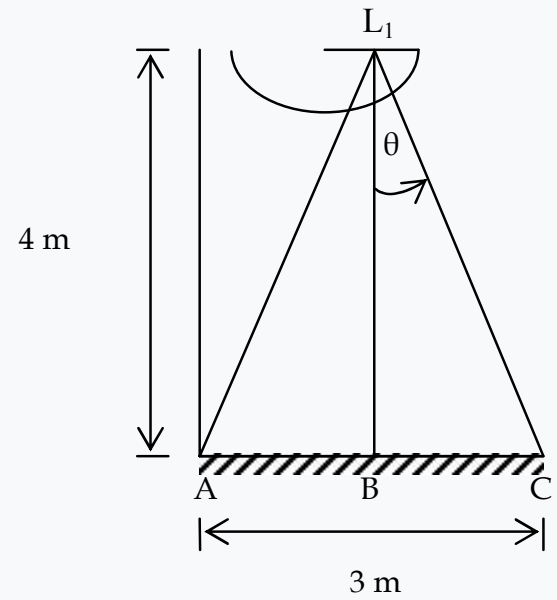

(a)

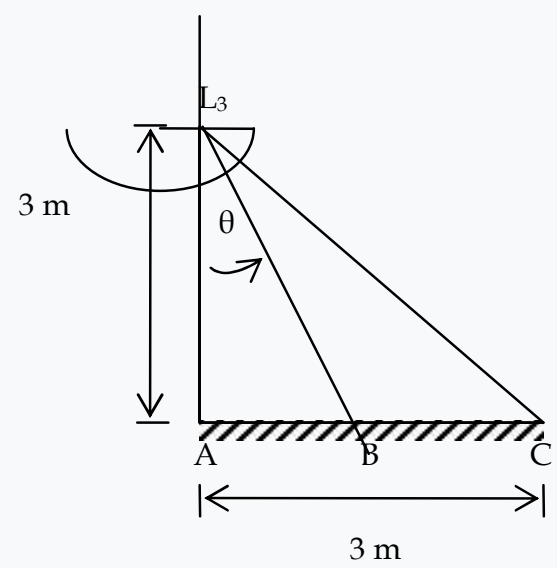

(c)

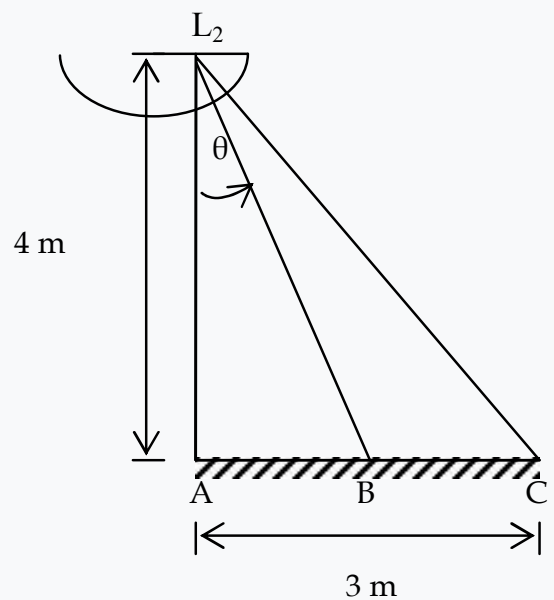

(b)

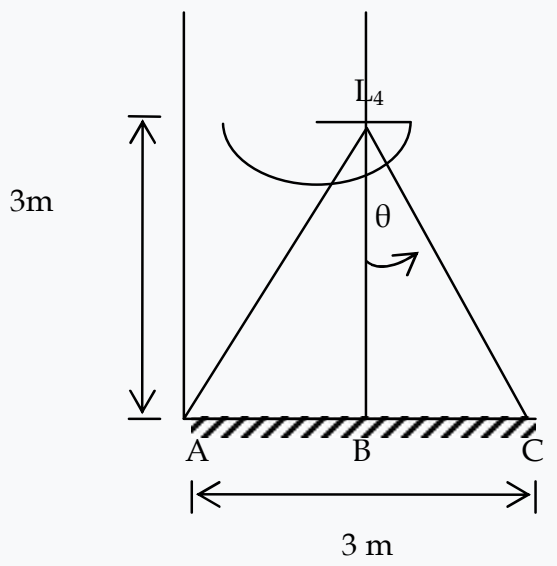

(d)

Figure 2. Different Position Location of Lamp at the same Room

By using theorem of phitagoras at figure 2 will be found by distance height of lamp evaluated from position of $\mathrm{b}$ is shown in calculation below. 


$$
L b=\sqrt{\left(t^{2}+s^{2}\right)}(2)
$$

Angle $\theta$ is obtained by determine angle cosine between $\mathrm{La}$ and $\mathrm{Lb}$ that is:

To obtain strength of lighting at a position as follows:

$$
\cos \theta=\frac{t}{\sqrt{\left(t^{2}+s^{2}\right)}}(3)
$$

To obtain strength of lighting at $\mathrm{b}$ position as follows:

$$
E_{a}=I / t^{2}(4)
$$

$$
E_{b}=I \cos \theta / \sqrt{\left(t^{2}+s^{2}\right)}
$$

Table 5. Strength of Lighting at Different Position of Lamp

\begin{tabular}{cccc}
\hline \multirow{2}{*}{ Lamp } & \multicolumn{4}{c}{ Strength of lighting [lx] } \\
\cline { 2 - 4 } & A position & B position & C position \\
\hline L1 & 4.9 & 5.97 & 4.9 \\
\hline L2 & 5.97 & 4.9 & 3.07 \\
\hline L3 & 10.6 & 7.59 & 3.75 \\
\hline L4 & 7.59 & 10.6 & 7.59 \\
\hline
\end{tabular}

\section{- Effect of Wall Color on Lighting}

Wall color affects the ability of light to reflect light flux in a room (Azis, M. A,Supriadi, B, \& Lesmono, A. D, 2016). There is a wall and ceiling color reflection factor which can be seen in the table 6:

Table 6. Reflection Factor Based on the Color of the Walls(Phillips Lighting Manual, 2015)

\begin{tabular}{cccc}
\hline Color & Reflection Factor & Color & Reflection Factor \\
\hline White & $0,7-0,8$ & Orange & $0,2-0,25$ \\
\hline Light Brown & $0,7-0,8$ & Dark Green & $0,1-0,15$ \\
\hline Light Yellow & $0,55-0,65$ & Dark Blue & $0,1-0,15$ \\
\hline Light Green & $0,45-0,5$ & Dark Red & $0,1-0,15$ \\
\hline Pink & $0,45-0,5$ & Black & 0,04 \\
\hline Blue Sky & $0,4-0,45$ & Gray & $0,25-0,35$ \\
\hline
\end{tabular}

Table 7.Power Comparison between LED, CFL and Incandescent Lamps(Phillips Lighting Manual, 2015)

\begin{tabular}{cccc} 
Lumen & LED & CFL & Incandescent \\
\hline $400-500$ & $6-7 \mathrm{~W}$ & $8-12 \mathrm{~W}$ & $40 \mathrm{~W}$ \\
\hline $650-850$ & $7-10 \mathrm{~W}$ & $13-18 \mathrm{~W}$ & $60 \mathrm{~W}$ \\
\hline $1000-1400$ & $12-13 \mathrm{~W}$ & $18-22 \mathrm{~W}$ & $75 \mathrm{~W}$ \\
\hline $1450-1700$ & $14-20 \mathrm{~W}$ & $23-30 \mathrm{~W}$ & $100 \mathrm{~W}$ \\
\hline 2700 & $25-28 \mathrm{~W}$ & $30-55 \mathrm{~W}$ & $150 \mathrm{~W}$ \\
\hline
\end{tabular}

\section{- Effects of Illumination on Eye Health}

Based on the results of research, eye health problems occur because they are in a room with non-standard lighting conditions (Lin, K. H, Su, C. C, Chen, Y.Y, Chu, P,2019). Poor lighting quality will cause the iris muscle to work harder to adjust the pupil to adjust to the intensity of the incoming light. If someone stays in the room for a long time it will cause eye fatigue, reduce work efficiency, and cause the potential for accidents.

\section{- Determination of the number of light points} namely:

Several factors influence the determination of the number of lighting points in a room, 
1. Room use (room function), every type of room use must have a strong need for lighting because every room has needs that are not the same as its use.

2. The scale of the shape of the room, the greater the scale of the room, the greater the capturing power of the lighting that must be needed.

3. The condition of the walls and top of a room (reflection factor), we need to know that the paint color on the walls and ceiling in a room can reverse or can absorb light.

4. Several types of lamps and armatures are used, each lamp and armature has a different design and characteristics.

4. The location of the placement and the number of lights in each existing room must be calculated in such a way, so that the room gets an even light beam.

The formula used to find the number of lighting points is:

$$
\begin{aligned}
& N=\frac{E \times P \times L}{\emptyset \times L L F \times C U \times n} \\
& \emptyset=W \times L / w
\end{aligned}
$$

Where:

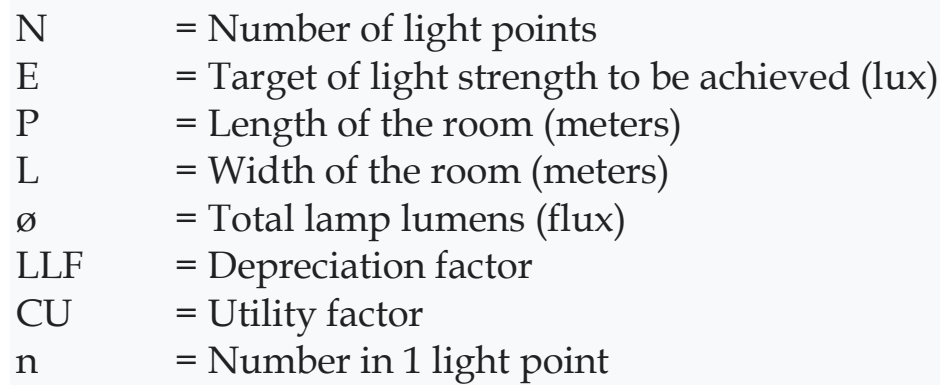

\section{Material \& Method}

The Faculty of Engineering, Universitas Medan Area has a building consisting of 4 (four) floors, where the 1st floor is used as an administration room and the 2nd, 3rd, and 4th floors are used as lecture rooms. The figure 3 and 4 is layout based on function and lighting point the 1st floor of the Faculty of Engineering building, University of Medan Area requires lighting improvements to match the standards so as to make vision comfortable and can improve service to students.

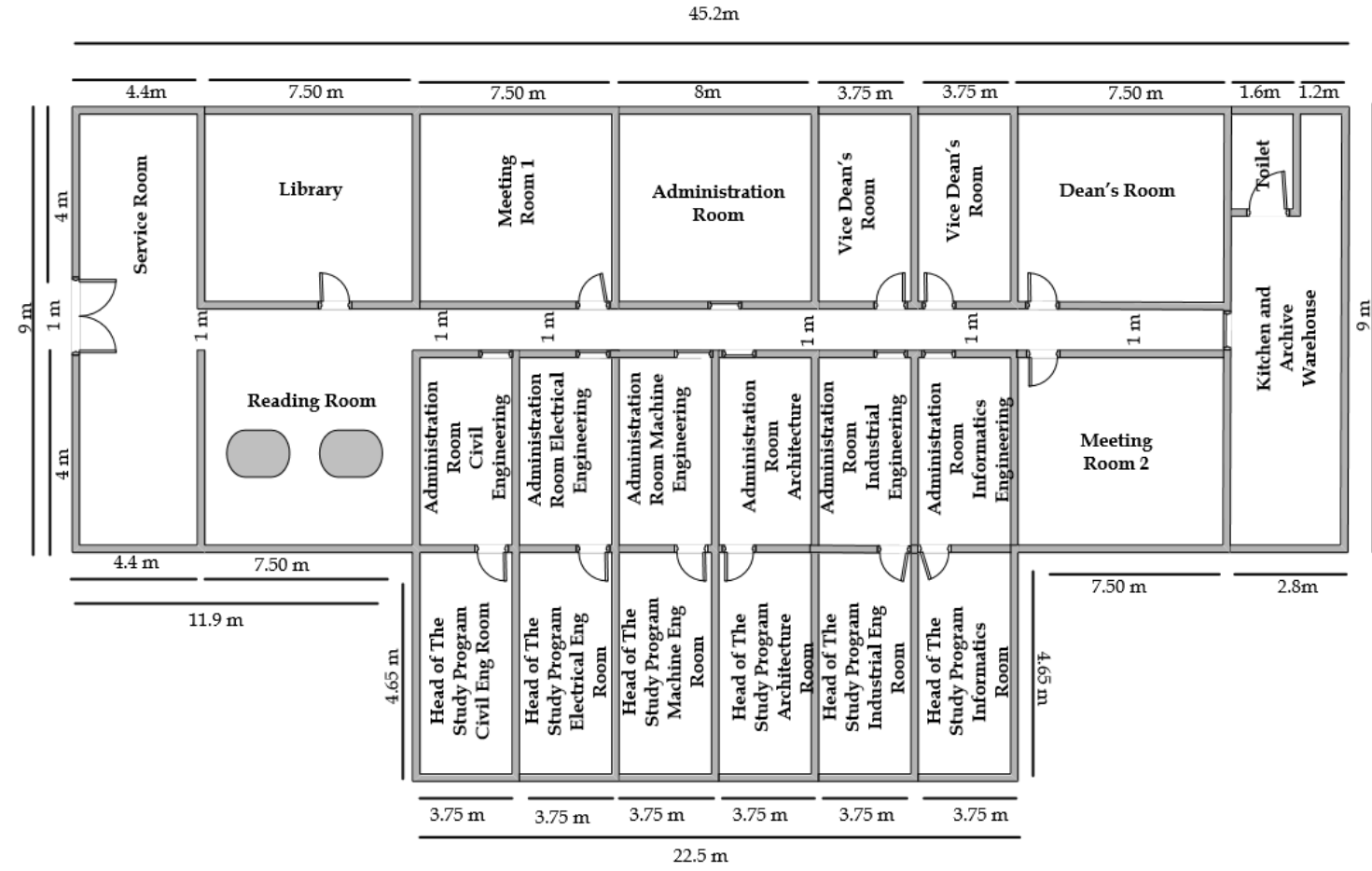

Figure 3.The Layout of the 1st Floor Room of Faculty Engineering, Universitas Medan Area 


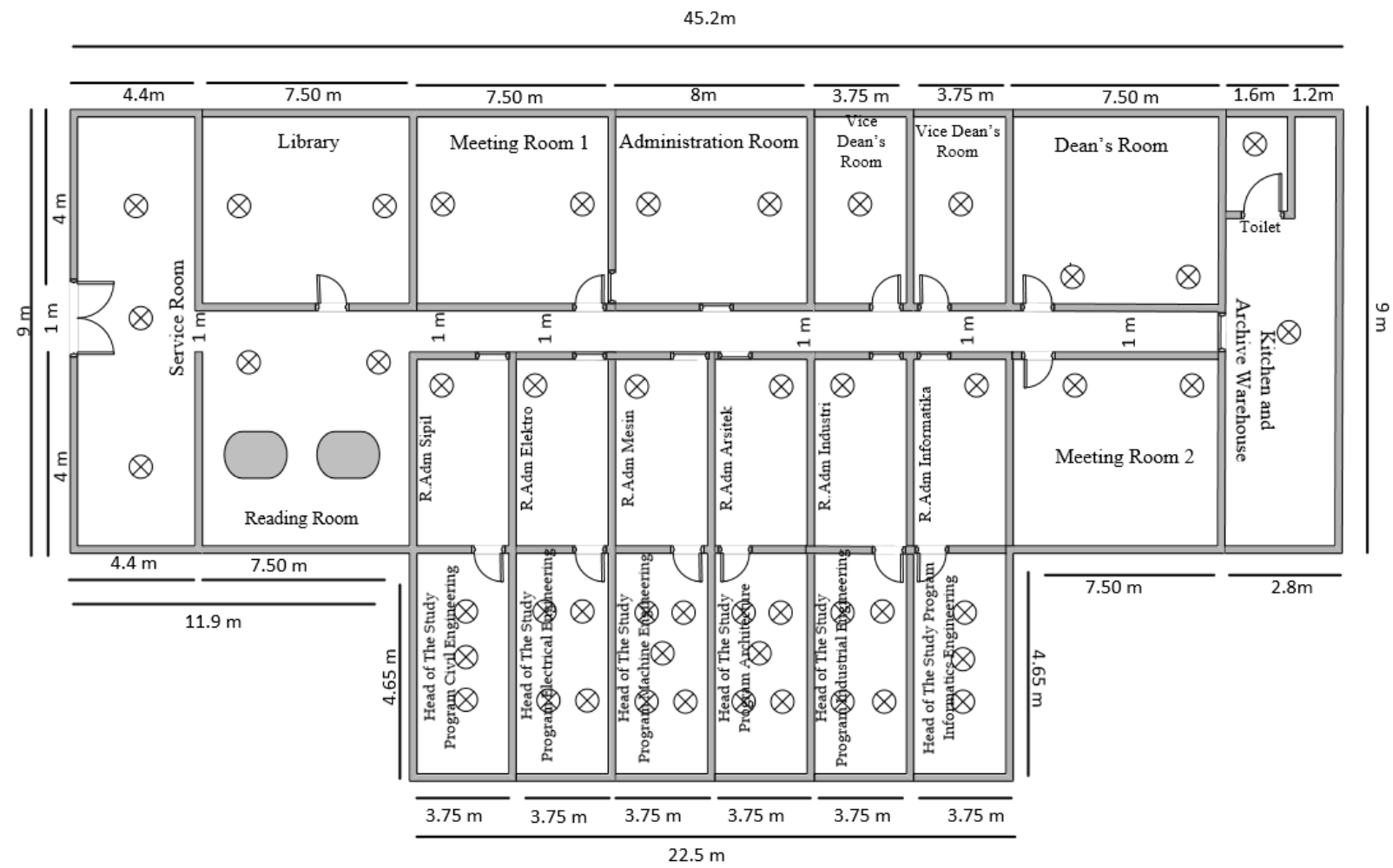

Figure 4.The Layout of The Light Points for the 1st Floor Room of Faculty Engineering, Universitas Medan Area

The research was carried out by measuring the light intensity using the Lux meter Kyoritsu illuminometer Model 5200 held on February 2, 2020 in order to obtain the value of the light intensity in each room. Based on these measurements, it is known that the value of light intensity throughout the room still has not reached the standard and it is necessary to make improvements by adding lighting points.

\section{Result and Discussion}

The measurement results of light intensity can be seen in the following table 7:

Table 8. The Measurement Results

\begin{tabular}{|c|c|c|c|}
\hline \multirow[b]{2}{*}{ No. } & \multirow[b]{2}{*}{ Room } & \multicolumn{2}{|c|}{ Illumination (Lux) } \\
\hline & & $\begin{array}{l}\text { Old Lighting } \\
\text { System }\end{array}$ & Lighting Standard \\
\hline 1 & Service Room & 75 & 100 \\
\hline 2 & Reading Room & 140 & 300 \\
\hline 3 & Library & 150 & 300 \\
\hline 4 & Head of The Study Program Civil Engineering & 200 & 350 \\
\hline 5 & Administration Room Civil Engineering & 112 & 350 \\
\hline 6 & Head of The Study Program Electrical Engineering & 180 & 350 \\
\hline 7 & Administration Room Electrical Engineering & 116 & 350 \\
\hline 8 & Head of The Study Program Machine Engineering & 350 & 350 \\
\hline 9 & Administration Room Machine Engineering & 100 & 350 \\
\hline 10 & Head of The Study Program Architecture & 300 & 350 \\
\hline 11 & Administration Room Architecture & 350 & 350 \\
\hline 12 & Head of The Study Program Industrial Engineering & 160 & 350 \\
\hline 13 & Administration Room Industrial Engineering & 92 & 350 \\
\hline 14 & Head of The Study Program Informatics Engineering & 200 & 350 \\
\hline 15 & Administration Room Informatics Engineering & 100 & 350 \\
\hline 16 & Meeting Room 1 & 150 & 300 \\
\hline 17 & Meeting Room 2 & 200 & 300 \\
\hline
\end{tabular}




\begin{tabular}{llcc}
\hline \multirow{2}{*}{ No. } & & \multicolumn{2}{c}{ Illumination (Lux) } \\
\cline { 3 - 4 } & & $\begin{array}{c}\text { Old Lighting } \\
\text { System }\end{array}$ & Lighting Standard \\
\hline 18 & Administration Room & 80 & 300 \\
\hline 19 & Dean's Room & 125 & 350 \\
\hline 20 & Vice Dean's Room & 100 & 350 \\
\hline 21 & Vice Dean's Room & 80 & 350 \\
\hline 22 & Kitchen and Archives Warehouse & 50 & 150 \\
\hline 23 & Toilet & 40 & 100 \\
\hline
\end{tabular}

Based on the measurement results in table 8, it is known that the old lighting system still does not fulfill the lighting standard. It needs improvement in lighting system. To get the number of additional light points, we using formula 6 and 7.

Then calculate the room for the Head of the Study Program Electrical Engineering, which is 4.65 meters long and 3.75 meters wide, using an $8 \mathrm{~W}$ CFL lamp which is equivalent to 40 Watts (table 6) and $\mathrm{L} / \mathrm{w}$ is 75 lumens, then:

$\varnothing=\mathrm{W} \times \mathrm{L} / \mathrm{w}=40$ watt $\times 75$ lumens $=3000$ lumens

$\mathrm{E}=350$ (Based on lumen requirements from Table 1)

$\mathrm{P}=4.65$ Meters

$\mathrm{L}=3.75$ Meters

$\mathrm{N}=1$

LLF $=0.8$ (between $0.7-0.8$ )

$\mathrm{CU}=50 \%$ (between $50 \%-60 \%$ )

$\varnothing=3000$ Lumens

So that

$\mathrm{N}=(\mathrm{E} \times \mathrm{W} \times \mathrm{L}) /(\varnothing \times \mathrm{LLF} \times \mathrm{CU} \times \mathrm{n})$

$\mathrm{N}=(350 \times 4.65 \times 3.75) /(3000 \times 0.8 \times 50 \% \times 1)$

$\mathrm{N}=6103.12 /(1200)=5.08$ (5 light points)

After measurements and calculations using formula 6 and 7 are obtained the change in the number of light point to match the lighting standard which shows in figure 5. Calculations and changes in the number of light point can be seen in table 9. While the change layout of the light points for the 1st floor room of Faculty Engineering, Universitas Medan Area can be seen in figure 6.
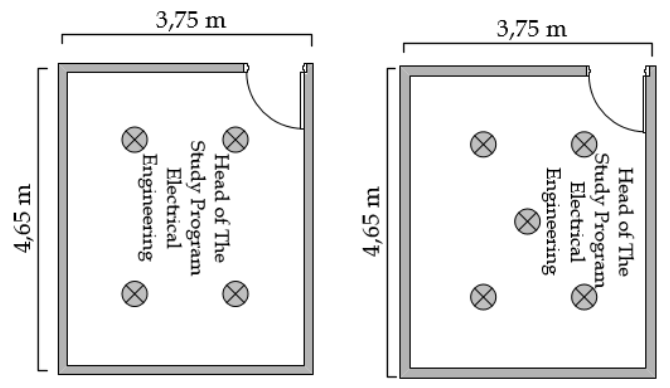

Figure 5. The Change in the Number of Light Points According to the Standard

Table9.The Change in the Number of Light Points According to the Standard for the 1st Floor Room of Faculty Engineering, Universitas Medan Area 


\begin{tabular}{|c|c|c|c|c|c|c|c|c|c|c|c|c|c|}
\hline No & Room & $\begin{array}{l}\text { Height } \\
\text { (m) }\end{array}$ & $\begin{array}{l}\text { Weight } \\
\text { (m) }\end{array}$ & $\begin{array}{l}\text { LED } \\
\text { Power }\end{array}$ & $\begin{array}{c}\text { Power } \\
\text { Equivalent } \\
\text { of } \\
\text { Incandesce } \\
\text { nt Lamps }\end{array}$ & $\begin{array}{l}\text { Lumen } \\
\text { /Watt }\end{array}$ & $\varnothing$ & LLF & $\mathrm{CU}$ & E & $\mathrm{n}$ & $\mathrm{N}$ & $\begin{array}{l}\text { Number } \\
\text { of Lights }\end{array}$ \\
\hline 1 & Service Room & 9 & 4,4 & 12 & 75 & 75 & 5625 & 0,8 & 0,5 & 100 & 1 & 2,76 & 3 \\
\hline 2 & Library & 7,5 & 4,5 & 12 & 75 & 75 & 5625 & 0,8 & 0,5 & 300 & 1 & 4,50 & 5 \\
\hline 3 & Reading Room & 7,5 & 4 & 12 & 75 & 75 & 5625 & 0,8 & 0,5 & 300 & 1 & 4,00 & 4 \\
\hline 4 & $\begin{array}{l}\text { Head of The Study } \\
\text { Program Civil } \\
\text { Engineering }\end{array}$ & 4,65 & 3,75 & 8 & 40 & 75 & 3000 & 0,8 & 0,5 & 350 & 1 & 5,09 & 5 \\
\hline 5 & $\begin{array}{l}\text { Administration } \\
\text { Room Civil } \\
\text { Engineering }\end{array}$ & 4 & 3,75 & 12 & 75 & 75 & 5625 & 0,8 & 0,5 & 350 & 1 & 2,33 & 2 \\
\hline 6 & $\begin{array}{l}\text { Head of The Study } \\
\text { Program Electrical } \\
\text { Engineering }\end{array}$ & 4,65 & 3,75 & 8 & 40 & 75 & 3000 & 0,8 & 0,5 & 350 & 1 & 5,09 & 5 \\
\hline 7 & $\begin{array}{l}\text { Administration } \\
\text { Room Electrical } \\
\text { Engineering }\end{array}$ & 4 & 3,75 & 12 & 75 & 75 & 5625 & 0,8 & 0,5 & 350 & 1 & 2,33 & 2 \\
\hline 8 & $\begin{array}{l}\text { Head of The Study } \\
\text { Program Machine } \\
\text { Engineering }\end{array}$ & 4,65 & 3,75 & 8 & 40 & 75 & 3000 & 0,8 & 0,5 & 350 & 1 & 5,09 & 5 \\
\hline 9 & $\begin{array}{l}\text { Administration } \\
\text { Room Machine } \\
\text { Engineering }\end{array}$ & 4 & 3,75 & 12 & 75 & 75 & 5625 & 0,8 & 0,5 & 350 & 1 & 2,33 & 2 \\
\hline 10 & $\begin{array}{l}\text { Head of The Study } \\
\text { Program } \\
\text { Architecture }\end{array}$ & 4,65 & 3,75 & 8 & 40 & 75 & 3000 & 0,8 & 0,5 & 350 & 1 & 5,09 & 5 \\
\hline 11 & $\begin{array}{l}\text { Administration } \\
\text { Room Architecture }\end{array}$ & 4 & 3,75 & 12 & 75 & 75 & 5625 & 0,8 & 0,5 & 350 & 1 & 2,33 & 2 \\
\hline 12 & $\begin{array}{l}\text { Head of The Study } \\
\text { Program Industrial } \\
\text { Engineering }\end{array}$ & 4,65 & 3,75 & 8 & 40 & 75 & 3000 & 0,8 & 0,5 & 350 & 1 & 5,09 & 5 \\
\hline 13 & $\begin{array}{l}\text { Administration } \\
\text { Room Industrial } \\
\text { Engineering }\end{array}$ & 4 & 3,75 & 12 & 75 & 75 & 5625 & 0,8 & 0,5 & 350 & 1 & 2,33 & 2 \\
\hline 14 & $\begin{array}{l}\text { Head of The Study } \\
\text { Program } \\
\text { Informatics } \\
\text { Engineering }\end{array}$ & 4,65 & 3,75 & 8 & 40 & 75 & 3000 & 0,8 & 0,5 & 350 & 1 & 5,09 & 5 \\
\hline 15 & $\begin{array}{l}\text { Administration } \\
\text { Room Informatics } \\
\text { Engineering }\end{array}$ & 4 & 3,75 & 12 & 75 & 75 & 5625 & 0,8 & 0,5 & 350 & 1 & 2,33 & 2 \\
\hline 16 & Meeting Room 1 & 7,5 & 4,5 & 12 & 75 & 75 & 5625 & 0,8 & 0,5 & 300 & 1 & 4,50 & 5 \\
\hline 17 & Meeting Room 2 & 7,5 & 4 & 12 & 75 & 75 & 5625 & 0,8 & 0,5 & 300 & 1 & 4,00 & 4 \\
\hline 18 & $\begin{array}{l}\text { Administration } \\
\text { Room }\end{array}$ & 8 & 4,5 & 12 & 75 & 75 & 5625 & 0,8 & 0,5 & 300 & 1 & 4,80 & 5 \\
\hline 19 & Dean's Room & 7,5 & 4,5 & 12 & 75 & 75 & 5625 & 0,8 & 0,5 & 350 & 1 & 5,25 & 5 \\
\hline 20 & Vice Dean's Room & 4,5 & 3,75 & 12 & 75 & 75 & 5625 & 0,8 & 0,5 & 350 & 1 & 2,63 & 3 \\
\hline 21 & Vice Dean's Room & 4,5 & 3,75 & 12 & 75 & 75 & 5625 & 0,8 & 0,5 & 350 & 1 & 2,63 & 3 \\
\hline 22 & $\begin{array}{l}\text { Kitchen and } \\
\text { Archieve } \\
\text { Warehouse }\end{array}$ & 9 & 2,8 & 8 & 40 & 75 & 3000 & 0,8 & 0,5 & 150 & 1 & 3,15 & 3 \\
\hline 23 & Toilet & 2 & 2 & 8 & 40 & 75 & 3000 & 0,8 & 0,5 & 100 & 1 & 0,33 & 1 \\
\hline
\end{tabular}




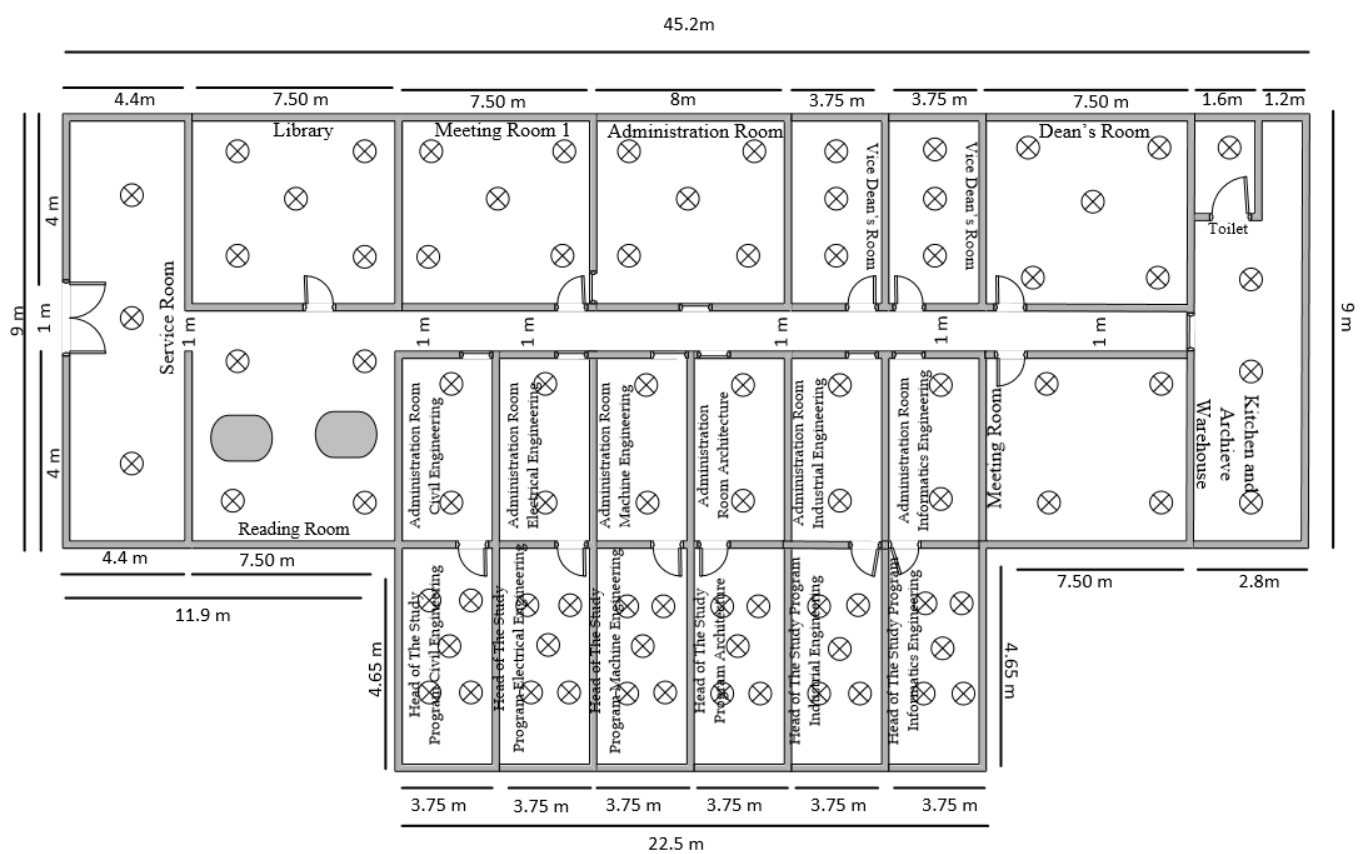

Figure 6. The Change Layout of The Light Points for the 1st Floor Room of Faculty Engineering, Universitas Medan Area

Based on the results of measurements and calculations, it is found that the shape of the room affects the quality of the lighting. The rectangular space requires $21 \%$ more light power than the circular shape and 50\% more than the triangle space shape based on the $x x$ table. This is because the rectangular shape has a larger area than other shapes. The Faculty of Engineering, University of Medan Area with $100 \%$ square space requires greater lighting.

The color of the walls also affects the quality of the lighting. The Faculty of Engineering, University of Medan Area is characterized by its blue color and has sky-blue walls. This results in a room reflectance factor of around $0.4-0.45$, thus requiring a larger lighting. White color can improve lighting quality because white color has a reflection factor of $0.7-0.8$.

The position of the lamp also has a role in producing the power of the lighting. Based on the $x x$ table, it is known that the position of the lamp in the middle has the greatest light strength, so that in this design the position of the lamp is placed in the middle. Whereas in some rooms, the position is placed on the edge of the room because of the need for light based on the placement of the work table.

\section{Conclusion}

From the simulation and calculation results, it is found that:

1. The quality of the lighting in a room is influenced by the shape of the room, the color of the walls, and the position of the lights.

2. The position of the lamp according to the comfort of vision is the location of the lamp in the middle of the room and is also adjusted to the placement of the work table.

3. The $100 \%$ area of the $100 \%$ square area of the engineering faculty building in the university, so it requires more lighting than other forms of space.

\section{Acknowledgments}

The author would like to thank the University of Medan Area for helping us to carry out this investigation.

\section{References}

E. Wahyu Pramon, K. Karnoto, and T. Nurhayati. (2018). Evaluasi Instalasi Listrik Pada Gedung Multi Centre of Excellent (Mce) Rumah Sakit Islam Sultan Agung Semarang. ELEKTRIKA, vol. 9, no. 1, p. 17. 
Lin, K. H, Su, C. C, Chen, Y.Y, Chu, P. (2019). The Effects of Lighting Problem on Eye Symptoms among Cleanroom Microscope Workers. International Journal of Environmental Research and Public Health 16(1):101

Hendarmin, R. G. D. (2017). Perancangan Instalasi Listrik Gedung Fakultas Ilmu Pendidikan Universitas Pendidikan Indonesia.Universitas Pendidikan Indonesia | repository.upi.edu | perpustakaan.upi.edu," pp.1-3.

Badan Standarisasi Nasional SNI 04-02252000, Persyaratan Umum Instalasi Listrik (2000), Yayasan PUIL, Jakarta.

Azis, M. A, Supriadi, B, \& Lesmono, A. D. (2016). Analisis Pengaruh Warna dan Ukuran Dinding Ruangan Terhadap Intensitas Pencahayaan. Jurnal Pembelajaran Fisika Vol. 5 No. 1 p. 35.

Feri, D, Anita, H. (2014). Analisa Perhitungan Kebutuhan Penerangan Pada Bangunan Rig Raisis (Offshore) Berdasarkan Class ABS dan BKI Berbasis Visual Basic. KAPAL Vol. 11 No. 1 p.5.

Dila, H. (2014). Perancangan Tata Cahaya Pada Interior Rumah Tinggal. HUMANIORA Vol. 5 No. 1 p. 258-264.

Adelakun, N. O, Olanipekun, B. A, \& Samuel, A. (2020). Design of Electrical Installation of a Storey Building. iJETRM, Vol. 4, No. 1 p. 28

Bērziña, K. (2019). Electrical Installation of Residential Buildings. RTU Press, Riga Technical University Institute of Power Engineering, Department of Electrical Power Supply

Schneider Electric. (2016). Electrical Installation Guide According to IEC International Standard.

Wagiman, K. R. (2017). Lighting System Design According to Different Standards in Office Building : A Technical and Economic Evaluations. International PostGraduate Conference on Applied Science \& Physics.

Orlight from Source to Site. (2014). Guide on Lighting Risks and Regulations. www.orlight.com

Bella, L, Pedace, A, Fragliasso, F. (2015). Indoor Lighting Equality : Effects of Different Wall Colours. Lighting Research and Technology 49 (1) 